Z Badań nad Książką i Księgozbiorami Historycznymi 2019. T. specjalny: Dla Niepodległej The Studies into the History of the Book and Book Collections 2019. Special issue: For an Independent Poland

ISSN 1897-0788, e-ISSN 2544-8730

www.bookhistory.uw.edu.pl

Oleksandr Sedliar

https://doi.org/10.33077/uw.25448730.zbkh.2020.203

Biblioteka Naukowa Lwowskiego Narodowego Uniwersytetu im. Iwana Franki

ol.sedlyar@gmail.com

ORCID 0000-0003-3787-9744

\title{
Działalność wydawniczna społecznych organizacji galicyjskich Rusinów (Ukraińców) w zakresie rozwoju idei oświaty ludu (lata 50. i 60. XIX w.)
}

\begin{abstract}
Publishing activity of Galician Ruthenians (Ukrainians) public organizations in the field of the development of the idea of people's education (50-60 ${ }^{\text {th }}$ years of XIX ${ }^{\text {th }}$ century)

One of the important factors determining the public activity of the Galician Ruthenians (Ukrainians) after 1848 was the realization of the idea of educating the people. In the 1850-1860's exclusively intellectuals were engaged in educational work; peasants and burghers were only recipients. At the time, the main attention was paid to the publication of educational literature for elementary schools and gymnasiums, as well as scientific, popular and religious lectures for intellectuals and common people. This was done by both private publishers and specially created non-governmental organizations such as the Russophile society Halytsko-Ruska Matytsia (since 1848) and the Ukrainophile society Prosvita (since 1868). Among the editions of Matytsia prevailing publications for the intelligentsia, Prosvita began its publishing activity mainly from small books for the common people.
\end{abstract}

Key words: history of Ukrainian book publishing - education of the people - popular literature - Galician Ruthenians (Ukrainians) - Halytsko-Ruska Matytsia society - Prosvita society.

Słowa kluczowe: historia książki ukraińskiej - oświata ludu - literatura popularna - Rusini (Ukraińcy) galicyjscy - towarzystwo Matyca Hałycko-Ruska - towarzystwo Proswita.

„Z Badań nad Książką i Księgozbiorami Historycznymi” - Udział zagranicznych recenzentów w ocenie publikacji; Stworzenie anglojęzycznej wersji wydawniczej publikacji; Digitalizacja tomów archiwalnych rocznika w celu zapewnienia otwartego dostępu do nich przez Internet oraz wdrożenie i utrzymanie cyfrowej platformy redakcyjnej - zadanie finansowane w ramach umowy nr 653/P-DUN/2019 ze środków Ministra Nauki i Szkolnictwa Wyższego przeznaczonych na działalność upowszechniającą naukę. 
Dla Rusinów (Ukraińców), którzy zamieszkiwali wschodnią część Królestwa Galicji i Lodomerii w monarchii austriackiej (od 1867 r. - monarchia austro-węgierska), jednym z najważniejszych zadań od czasów Wiosny Ludów (1848 r.) do I wojny światowej była oświata ludu. Byli oni niezadowoleni ze swojej pozycji w austriackiej Galicji. Ze względu na słabszą pozycję w życiu politycznym, gospodarczym i kulturalnym nie czuli się równi innym narodom. Nie mieli własnej arystokracji, a inteligencja o narodowej świadomości zaczęła formować się dopiero w połowie XIX w. Bezwzględną większość ludu ukraińskiego stanowili słabo wykształceni i niewykształceni chłopi oraz drobnomieszczanie. Dla społecznych liderów Rusinów szybko stało się jasne, że poprawa ich pozycji w kraju może nastąpić tylko dzięki wzrostowi znaczenia ruskich chłopów w polityce, gospodarce oraz innych obszarach życia publicznego.

W celu włączenia słabo wykształconych chłopów i mieszczan do aktywnego życia społecznego, by pomóc im modernizować archaiczną gospodarkę i choć częściowo przygotować do nowych wyzwań, które pojawiały licznie się w drugej połowie XIX w., Ukraińscy działacze społeczni starali się realizować program oświaty ludu, np. przez wydawanie taniej popularnej literatury. Konieczne było nie tylko zaoferowanie odpowiedniej wiedzy, ale także ukształtowanie ruskich (ukraińskich) postaw patriotycznych; ówczesny oficjalny system edukacji nie był wystarczający. Ruski program oświatowy musiał go w tym zakresie uzupełnić, a także stać się alternatywą dla podobnych polskich projektów oświatowych.

Z jednej strony program oświatowy dla Rusinów galicyjskich był czymś oczywistym, potrzeba jego wdrożenia nie wymagała specjalnego uzasadnienia. Powinien on obejmować szereg działań edukacyjnych mających na celu: wyeliminowanie analfabetyzmu, rozpowszechnianie popularnej literatury, promowanie nowych form prowadzenia gospodarstwa, odnowę moralnego (chrześcijańskiego) stylu życia oraz organizowanie publicznych wydarzeń o charakterze narodowo-kulturalnym. Działalnością oświatową zajmować się miała ruska inteligencja, przede wszystkim księża greckokatoliccy, a także niektóre organizacje społeczne. Pierwszymi z nich były założone w $1848 \mathrm{r}$. towarzystwo Matyca Hałycko-Ruska (Macierz Halicko-Ruska), które z biegiem czasu opanowali rusofile ${ }^{1}$, i utworzona w 1868 r. w dużej mierze jako

1 Rusofile - ruch narodowo-kulturowy wśród galicyjskich Rusinów (Ukraińców) drugiej połowy XIX - początku XX w. Wierzyli, że Rusini rozwijali się w przeszłości i powinni rozwijać się dalej jako integralna część wschodniosłowiańskiej „ruskiej” (wszechruskiej) przestrzeni. Ruch rusofilski był konserwatywnym i bardzo heterogenicznym. W XIX w. większość rusofilów ograniczała się do wyrażania szacunku dla tradycji językowych, religijnych i kulturowych Rusinów galicyjskich, oponując galicyjskim Polakom i unikając bezpośrednich związków z Imperium Rosyjskim. Jednak warianty języka literackiego, którymi się posługiwali, mniej więcej zbliżały się do języka rosyjskiego, a prasa rusofilska nazywała rodaków „russkimi”. Następnie więzi z Rosją stały się ważniejsze 
alternatywa do Matycy organizacja galicyjskich narodowców (ukrainofilów)² towarzystwo Proswita.

$\mathrm{Z}$ drugiej strony tworzeniu programu oświatowego, a nawet zrozumieniu samej idei oświaty ludu, towarzyszyły trudności i kontrowersje. Teoretyczne kierunki prac w tym zakresie rozmywały się, gdy dochodziło do ich praktycznej realizacji. Nie wiedziano, jak zachęcać niewykształconych chłopów do zdobywania wiedzy, jak i gdzie pozyskiwać fundusze na działania oświatowe, jak pisać teksty, które trafią do słabo wykształconego odbiorcy, wreszcie w jaki sposób pogodzić tradycyjne moralne i religijne wychowanie chłopów - prowadzone do tej pory przez duchowieństwo - z popularyzacją nowych trendów i wiedzy.

Dla galicyjskich Rusinów zupełnie inną kwestią była oświata wykształconych, czyli popularyzacja nowej wiedzy o ruskiej historii, literaturze i sztuce wśród, w dużej mierze, zdenacjonalizowanej inteligencji. W połowie XIX w. toczyły się ostre dyskusje dotyczące sposobów rozwijania ruskiego (ukraińskiego) języka literackiego w Galicji. Miały one również wpływ na realizację programu oświatowego. Rusofile i ukrainofile przygotowywali odpowiednie książki w różnych wersjach języka literackiego. Proces oddziaływania inteligencji na chłopów i mieszczan w celu szerzenia wiedzy był więc złożony, zachodził powoli i towarzyszyła mu interakcja różnych czynników (społecznych, polityczynych i ekonomicznych).

Celem niniejszego artykułu jest analiza programu działań oświatowych Rusinów galicyjskich i początkowego etapu jego realizacji, który trwał od powołania towarzystwa kultularno-oświatowego Matyca Hałycko-Ruska w lipcu 1848 r. do końca lat 60 . XIX w.

Bazę źródłową stanowią artykuły z galicyjskiej ruskiej prasy, jak również dokumentacja archiwalna Matycy (zespół 148 Centralnego Państwowego Archiwum Historycznego Ukrainy we Lwowie), wydawnictwa tego stowarzyszenia i towarzystwa Proswita. W szczególności opierano się na tekstach zamieszczonych - w latach 50. XIX w. - w czasopismach „Zoria Hałyćka” i „Wistnyk dla Rusyniw Awstrijskoji derżawy”, a także - dla następnej dekady - w rusofilskim „Słowie” oraz ukrainofilskich „Mecie” i „Prawdzie”.

Do tej pory nie ukazała się żadna publikacja gruntownie omawiająca rozwój oświaty ludowej Rusinów galicyjskich w latach 50. i 60. XIX w. Znacznie

dla rusofilów, ale nie mogło to zrekompensować utraty ich popularności wśród ruskiej (ukraińskiej) ludności Galicji przed I wojną światową.

2 Narodowcy (ukrainofile) - opozycjny rusofilskiemu ruch narodowo-kulturowy wśród galicyjskich Rusinów (Ukraińców), który powstał w latach 60. XIX w. pod wpływem idei zapożyczonych z Ukrainy Naddnieprzańskiej. Narodowcy uważali Rusinów galicyjskich za część narodu małoruskiego (ukraińskiego), odrębnego od Polaków i Rosjan. Dla nich ważny był rozwój języka literackiego na poziomie lokalnym (ludowym). Na przełomie XIX i XX w. ukrainofile osiągnąli znaczącą przewagę nad galicyjskimi rusofilami. Jednocześnie pojęcie „narodowcy” wychodzi z użycia, podobnie jak etnonim „Rusini” stopniowo zostaje zastępowany przez etnonim „Ukraińcy”. 
lepiej została natomiast zbadana działalność wydawnicza stowarzyszeń Matyca Hałycko-Ruska i Proswita. W szczególności o pierwszym okresie działalności Matycy opublikowało prace naukowe szereg ukraińskich i zagranicznych historyków. Autorem najdokładniejszej z nich jest lwowski badacz Oleksii Suchyj ${ }^{3}$. Dobrze prześledzone zostały główne wydarzenia z historii towarzystwa, przeanalizowano przebieg i wyniki ogólnych zebrań, omówiono wszystkie znaczące wydawnictwa. Mniej uwagi poświęcono kwestii, w jaki sposób działalność wydawnicza Matycy była skorelowana z programem oświatowym Rusinów galicyjskich w połowie XIX w. Utworzenie i pierwsze lata Towarzystwa Proswita szczegółowo przeanalizował lwowski historyk Volodymyr Paszuk 4 . W ukraińskiej historiografii działalność oświatowa i wydawnicza ukraińskich organizacji społecznych w Galicji pod koniec XIX i na początku XX w. jest zbadana znacznie lepiej niż ta z połowy XIX w.

Badany okres można podzielić na cztery etapy. Podczas pierwszego (lata 1848-1851) miała miejsce formacja organizacyjna towarzystwa Matyca Hałycko-Ruska, zaczęły się rozwijać także jego wydawnictwa książkowe. Za podstawę programu oświatowego Rusini galicyjscy uważali wówczas rozwój szkół elementarnych we wsiach i eliminację analfabetyzmu. Drugi etap trwał do końca lat 50. XIX w. Był to czas znacznego obniżenia aktywności Matycy i prawie całkowitej utraty zainteresowania oświatą ludową wśród Rusinów galicyjskich. Kolejny etap rozpoczął się wraz z wewnątrzpolitycznymi zmianami w Austrii w latach 1860-1861 i trwał do walnego zebrania Matycy w 1865 r. W tym czasie w Galicji pojawiły się pierwsze ruskie czasopisma o charakterze oświatowym, skierowane przede wszystkim do chłopów i drobnomieszczan. Wówczas pojawili się również pierwsi ukrainofile, a wszyscy Rusini galicyjscy, niezależnie od narodowo-kulturowych poglądów, nadal uznawali autorytet Matycy jako głównego organizatora pracy oświatowej. Wreszcie, ostatni, czwarty etap obejmuje drugą połowę lat 60. XIX w., kiedy stało się oczywiste, że Matyca Hałycko-Ruska nie wywiązała się ze swoich statutowych zadań. Narodowcy (ukrainofile) założyli towarzystwo oświatowe (Proswitę) i zaczęli wcielać w życie własny wariant programu oświatowego. Ruskie społeczeństwo powoli zaczynało dostrzegać potrzebę nowych modeli kształcenia niezamożnych,

F.I. Steblij, M.M. Kril', Halickâ̂ matica vo L'vove, [w:] Slavânskie maticy. XIX vek. Č. 1, Moskva 1996, s. 190-233; O. Suhij, Vid rusofil 'stva do moskvofil'stva (rosijs 'kij činnik u gromads 'kij dumcì ta suspil'no-političnomu žitti galic'kih ukraïnciv u XIX stolitti), L'vìv 2003, s. 146-249; A.V. Vendland, Rusofili Galičini. Ukrä̈ns'ki konservatori miž Avstriêû ta Rosiêû, 1848-1915, L'vìv 2015, s. 71-82.

4 V. Pašuk, Tovaristvo „Prosvita”. Započatkuvannâ vidavničoï diâl'nostì, „Visnik L'vìvs'koï Komercìjnoï Akademiï. Serîa gumanìtarnì nauki” 2011, vip. 10, s. 170-182; tenże, Tovaristvo „Prosvita”. Peršì vidannâ na social'no-ekonomičnu tematiku. 1869-1874 rr., „Narodoznavčì Zošiti”" 2012, nr 6, s. 1171-1186; tenże, Religìjno-cerkovna tematika u perših vidannâh Tovaristva „Prosvita”" 1868-1871 rr., [w:] İstoriâ relìgï v Ukraïnì. Kn. 1, L'vìv 2014, s. 217-235. 
w których kluczowe miejsce powinna zająć promocja czytelnictwa (i tworzenie czytelni we wsiach i mniejszych miasteczkach) oraz znaczny wzrost propozycji wydawniczych dla chłopów realizowany poprzez regularną publikację popularnych książeczek o różnorodnej tematyce.

Działalność oświatowa Rusinów galicyjskich, która rozpoczęła się jeszcze na początku XIX w., znacznie przyśpieszyła w 1848 r. Stało się to możliwe dzięki znacznym wewnątrzpolitycznym zmianom, spowodowanym przez rewolucję w Cesarstwie Austriackim. Oczywiście zmiany te wystąpiły niespodziewanie, a Rusini nie byli na nie dostatecznie przygotowani. Chociaż jeszcze przed 1848 r. mała grupa ruskich inteligentów ze Lwowa zastanawiała się nad planem założenia stowarzyszenia opartego na modelu Macierzy funkcjonujących już wśród innych narodów słowiańskich ${ }^{5}$, jednak do jego realizacji było jeszcze bardzo daleko. Rewolucja 1848 r. stworzyła Rusinom nowe możliwości, o których wcześniej nie mogli nawet marzyć.

Jedną z ważnych kwestii, które zajmowały ruskich działaczy społecznych od założenia Głównej Rady Ruskiej w maju 1848 r., była organizacja procesu kształcenia, upowszechniania wiedzy i kultury. Zagadnienie to pozostawało aktualne aż do upadku Austro-Węgier, a pojęcie „oświata ludu” stale było obecne na łamach ruskich czasopism. Już w 1848 r. Rusini określili dwa główne kierunki, w których chcieliby realizować swój program oświatowy. Były to założenie i rozwój szkół elementarnych we wszystkich ruskich wsiach oraz utworzenie organizacji społecznej, która publikowałaby tanią literaturę dla ludu.

Nie była to nowatorska strategia. Szkoły, które miały zmniejszyć odsetek analfabetów wśród młodzieży ruskiej, pojawiały się na wsiach już kilka dziesięcioleci przed rokiem $1848 \mathrm{r}$. W warunkach porewolucyjnych trzeba było tylko przyśpieszyć proces ich tworzenia. W 1848 r. i przez następne dwie dekady szkoły elementarne dla ruskich dzieci pozostawały pod kontrolą Kościoła greckokatolickiego. Towarzystwo oświatowe, jak wspomniano wcześniej, miało działać na wzór słowiańskich Macierzy, przede wszystkim Macierzy czeskiej (Matice česká), chociaż dostosowane do warunków życia Rusinów galicyjskich (prawie całkowity brak narodowej burżuazji, wiodąca rola duchowieństwa, bardzo niski poziom edukacji chłopów).

Zagadnienia szkolnictwa ogólnie, doniesienia o zakładaniu nowych szkół elementarnych (trywialnych i parafialnych) we wschodniogalicyjskich wsiach i miasteczkach, uzasadnianie ich znaczenia i konieczności powoływania pojawiały się często na łamach ruskich czasopism w latach 1849-1850. Doniesienia te były bardzo optymistyczne, ich autorzy uważali, że szybka rozbudowa sieci szkół ludowych na tle nowych szans, jakie chłopi otrzymali po zniesieniu pańszczyzny wkrótce pomoże rozwiązać znaczną część problemów wynikających

5 F.I. Steblij, M. M., Kril', Halickâ̂ matica vo L'vove..., s. 198. 
z braku wykształcenia. Takie nadzieje były płonne. Już w $1851 \mathrm{r}$. w ruskich czasopismach pojawiło się kilka bardziej zrównoważonych i krytycznych publikacji, w których stwierdzano, że nowe szkoły powstały nie z oddolnej potrzeby chłopów, ale z uporczywego apelu austriackich urzędników i greckokatolickich księży, że wynagrodzenie nauczycieli było niewystarczające, brakowało podręczników i, co ważne, literatury do czytania po ukończeniu szkoły $^{6}$. Chłopi nie widzieli potrzeby edukacji szkolnej swoich dzieci. W wielu wsiach szkoły w latach 50. i 60. XIX w. nie zaczęły funkcjonować. We wsiach, w których działały, dzieci, które nauczyły się czytać i pisać po pewnym czasie po zakończeniu edukacji traciły te umiejętności ze względu na brak lektur. Dopiero po kilku dekadach, w latach 80. i 90. XIX w., a w niektórych powiatach nawet później, czytanie stało się powszechną praktyką ruskich włościan.

Organizacją społeczną, która miała zajmować się oświatą ludu, zostało założone w 1848 r. towarzystwo Matyca Hałycko-Ruska. O jego utworzeniu poinformowano 16 czerwca tego roku na posiedzeniu Głównej Rady Ruskiej ${ }^{7}$. W dniach 19-26 X 1848 r. we Lwowie odbył się Sobór Uczonych Ruskich. Jego uczestnicy omówili szereg ważnych kwestii dotyczących ukraińskiej polityki oświatowej i naukowej, wydania podręczników, tworzącego się języka ukraińskiego, a także ponownie ogłosili 25 października powołanie Matycy Hałycko-Ruskiej ${ }^{8}$. Taki dziwny, na pierwszy rzut oka, krok wiązał się z ścieraniem się dwóch różnych strategii oświatowych w środowisku ruskiej inteligencji.

Założycielami Matycy z czerwca 1848 r. byli przedstawiciele lwowskiego duchowieństwa greckokatolickiego i ruskiej świeckiej inteligencji ze Lwowa. Wszyscy byli ściśle związani z kierownictwem archidiecezji lwowskiej Kościoła greckokatolickiego, a pierwszym prezesem nowo utworzonego towarzystwa został kanonik Mychajło Kuzemskyj (Kuziemski) - wtedy zastępca przewodniczącego Głównej Rady Ruskiej. Ich rozumienie oświaty ludu i zadań Matycy było dość archaiczne i oparte na doświadczeniu wypełniania duszpasterskich zadań przez ówczesny kler. Oznaczało to, że realizatorzy programu oświatowego mieli koncentrować się na zaspokajaniu potrzeb edukacji na poziomie elementarnym pod patronatem Kościoła, a także sprzyjać pogłębianiu pobożności, moralności chłopów oraz drobnomieszczan, walczyć z ich szkodliwymi przyzwyczajeniami i zabobonami. Dopiero druga w kolejności była

6 Grabovič’ paroch" Kovalěvki, Z" Stanislavovskogo, „Zorâ Galicka” 29.01.1851, s. 70-71; Z" Sambörskogo okruga 8/20 maă, „Věstnik" dlâ Rusinov" Avstrìjskoi deržavy” 12.06.1851, s. 251252; Z" Bolehovskogo, o postupé škol" i izobrazovanii narodnom", tamże 24.07.1851, s. 322-323; 26.07.1851, s. 326.

Golovna Rus'ka Rada (1848-1851). Protokoli zasidan' i kniga korespondencï̈, za red. O. Turiâ, uporâdn. U. Krištalovič ta İ. Svarnik, L'vìv 2002, s. 33.

8 Istoričeskij očerk" osnovaniâ Galicko-ruskoi Maticě i spravozdan'e pervogo soboru učenyh" russkih" i lûbitelej narodnogo prosvěŝeniâ, sostavleno Â. Golovackim", vo L'vově 1850, s. CXIIICXV. 
edukacja z zakresu przyrodoznawstwa, prowadzenia gospodarstwa, historii narodowej itp. Program wydawniczy Matycy w tym przypadku uwzględniałby potrzeby chłopstwa i drobnomieszczaństwa odnosnie literatury edukacyjnej (elementarze, czytanki), religijno-pouczającej (modlitewniki, żywoty świętych, być może, krótkie opowieści o pouczających treściach) i uproszczonej popularnonaukowej.

Jednak już latem 1848 r. wśród inteligencji ruskiej znalazły się osoby, które nie zgadzały się z taką interpretacją pracy oświatowej. Młody prawnik Iwan Borysikewicz podjął się prezentacji ich stanowiska kierownictwu Głównej Rady Ruskiej i nowo utworzonej Matycy. Jego zwolennicy (nieliczna, jednak bardzo aktywna grupa inteligentów) uważali, że Matyca Hałycko-Ruska powinna zajmować się nie tylko publikacją literatury popularnej, ale także publikować studia nad historią i kulturą narodową, przedstawiać rzeczywisty dorobek intelektualny Rusinów na obszarze monarchii habsburskiej i w Europie w ogóle. Byli więc zdania, że towarzystwo oświatowe powinno publikować również literaturę na potrzeby inteligencji, zachęcać do badań i rozwijać język literacki. Dla I. Borysikewicza i jego kolegów reprezentowana przez Rusinów lwowskich wizja programu oświatowego była zbyt wąska, klerykalna i prowincjalna9 .

W celu pogodzenia różnych stanowisk zwołano zjazd ruskich uczonych (Sobór Uczonych Ruskich). Miano na nim przedyskutować propozycje wszystkich środowisk zajmujących się pracą oświatową, koordynować ich dalsze działania, ustalić priorytety wydawnicze, rozstrzygać kontrowersje językowe i gramatyczne, a wreszcie zainicjować potężne działanie promocyjne, aby udowodnić, że Rusini galicyjscy dzięki rewolucji rozpoczynają nowy etap w rozwoju narodowo-kulturowym. Pod wieloma względami zjazd i jego decyzje stały się kompromisem ${ }^{10}$. W przypadku poszukiwania strategii realizacji programu oswiatowego, był to kompromis pomiędzy liderami społecznymi i politycznymi Rusinów (tzw. świętojurcami), którzy dysponowali zasobami administracyjnymi Kościoła greckokatolickiego i mieli duży wpływ na księży (głównych wykonawców pracy oświatowej), oraz aktywnymi intelektualistami, którzy mieli możliwość i chęć pisania tekstów naukowych i popularnonaukowych, podtrzymywali kontakty z uczonymi i działaczami społecznymi spoza Galicji. Kompromis ten stał się cechą definiującą aktywność Matycy Hałycko-Ruskiej i w ogóle działalność oświatową Rusinów galicyjskich przez następne kilka dziesięcioleci po roku 1848.

Pierwsze edycje towarzystwa dobrze ilustrują dwoistość jego programu oświatowego. Wśród nich są podręczniki dla szkół (Ruski elementarz Antona

9 Korespondenciâ Âkova Golovac'kogo v lïtah 1835-49, vidav K. Studins'kij, L'vìv 1909, s. 242-243, 291-292.

10 O. Suhij, Vid rusofil'stva do moskvofil'stva..., s. 191-192. 
Dobrianskiego (Dobrzańskiego), Czytanka dla małych dzieci Markijana Szaszkewycza (Szaszkiewicza), Gramatyka języka ruskiego Jakowa Hołowackiego (Głowackiego), Rozmowy rusko-niemieckie Iwana Hurkewycza (Hurkiewicza)), modlitewniki i lektura religijno-pouczająca (Dwa stowa cerkiewne i O grecko-stowiańskim obrzadku katolickim Mychajła Małynowskiego (Malinowskiego), Żywot świętego Eustachego Mychajła Borodajkewycza (Borodajkiewicza)), wydania dla inteligencji (Badania języka południoworuskiego i Trzy wykłady wstępne J. Hołowackiego, Szkic założenia Hałycko-Ruskiej Matyci). Działalność wydawnicza była mniej lub bardziej aktywna aż do $1852 \mathrm{r}$. Później książki Matycy również ukazywały się, ale zdecydowanie rzadziej.

Pierwszy okres działalności Matycy zakończył się w 1851 r. Po zatwierdzeniu nowej wersji statutu stowarzyszenia (8 II 1851) jej aktywnośc zaczęła słabnąć. Zgodnie ze statutem walne zgromadzenia powinny były odbywać się corocznie, jednak nie były zwoływane - po walnym zgromadzeniu w $1850 \mathrm{r}$., następne odbyło się dopiero w 1864 r.! Również posiedzenia członków odbywały się rzadko i nieregularnie. W latach $1850-1851$ pojawiły się czynniki, które zdeterminowały działalność towarzystwa w następnym okresie: 1) stopniowy spadek aktywności społecznej i intelektualnej ruskiej inteligencji na tle wygasania impulsu nadanego przez rewolucję 1848 r.; 2) brak tekstów do publikacji w ramach programu wydawniczego Matycy - niestety dość szybko okazało się, że nie uda się zrealizować we właściwy sposób założonych celów; 3) przekierowanie uwagi przewodniczących i działaczy Matycy i generalnie przywódców Rusinów galicyjskich z początku lat 50. XIX w. na zbiórkę środków na organizację i budowę Narodnego Domu (Domu Ludowego) we Lwowie; 4) nasilenie sporów dotyczących sposobów rozwoju ruskiego języka literackiego, brak uzgodnionej pozycji wśród członków stowarzyszenia, jaki powinien być język jego publikacji - ściślej związany ze starożytnym ruskim językiem literackim lub współczesnym językiem ludu wiejskiego; 5) działania zarządu Matycy ukierunkowane na oszczędzanie środków finasowych, nie inwestowanie w projekty wydawnicze o wątpliwej rentowności.

Drugi okres działalności Matycy Hałycko-Ruskiej przypada na lata 18521860 i odznaczał się znikomą jej aktywnością ${ }^{11}$ oraz pierwszymi oznakami niezadowolenia społecznego widocznymi w ruskiej prasie. W tym czasie działalność wydawnicza była rzeczywiście kontrolowana przez niewielką grupę ludzi z wydziału towarzystwa, którzy mieli przekonania rusofilskie. Wyraźny spadek aktywności działacze tłumaczyli dwiema przyczynami. Po pierwsze, władza krajowa nie zatwierdziła nowej wersji statutu, który trzeba było zmienić z powodu nowych wymogów austriackiego ustawodawstwa 1852 r. A po

11 O. Suhij, Vid rusofil'stva do moskvofil'stva..., s. 200-202; A.V. Vendland, Rusofili Galičini..., s. 75-77. 
drugie, trzeba było realizować edycje wcześniej rozpoczęte i zebrać fundusze na nowe wydania ${ }^{12}$. Oprócz tych oficjalnie potwierdzonych przyczyn były i inne, przede wszystkim niechęć zarządu Matycy do intensywnego angażowania się w działalność oświatową na tle spadku zainteresowania inteligencji ruskiej tym tematem i zwiększonej uwagi galicyjskich władz krajowych na rzeczywiste lub możliwe przejawy rusofilizmu ze strony Rusinów.

W rezultacie ostrożna i kompromisowa taktyka Matycy została ustalona w połowie lat 50. XIX w. Projekty wydawnicze były realizowane przez niewielką grupę rusofilskich księży (J. Hołowackyj, M. Małynowskyj, Anton Petruszewycz (Pietruszewicz)) pod przewodnictwem prezesa towarzystwa M. Kuzemskiego. Pracowali oni, nie zwracając uwagi na potrzeby społeczeństwa i nie angażując innych w przygotowanie, recenzowanie lub redakcję tekstów. W tym czasie Matyca Hałycko-Ruska publikowała głównie modlitewniki i prace naukowe. W praktyce realizacja programu wydawniczego została oddana kilku osobom. Reszta członków z powodu niezwoływania walnych zgromadzeń oraz niemożliwości omawiania i weryfikowania programu oświatowego została odsunięta od podejmowania decyzji. Ten stan rzeczy wywołał niezadowolenie wśród wielu działaczy. W ruskich czasopismach pojawiło się kilka artykułów krytykujących bezczynności Matycy ${ }^{13}$. Jednak nie miały one konkretnych skutków. Ruskie stowarzyszenie oświatowe pracowało wówczas z minimalną wydajnością. Całkowite zaniechanie prac wydawniczych było niemożliwe ze względu na członków, którzy opłacali składki, ale nie było woli i odwagi podejmowania nowych inicjatyw i realizowania nowych pomysłów.

Faktyczny stan Matycy w latach 50. XIX w. ilustruje sprawa publikacji periodyku towarzystwa. Jeszcze w 1848 r. członkowie zdecydowali, że dobrym pomysłem byłoby wydanie czasopisma w celu upowszechniania oświaty. Zwierzchnicy zasadniczo nie byli przeciwni tej idei, ale odwlekali jej realizację. Wreszcie, na początku lat 50. XIX w. Matyca wezwała wszystkich do zgłoszenia swoich propozycji dotyczących przyszłego periodyku. Otrzymano kilka listów z sugestiami ${ }^{14}$, ale nie zostały one wdrożone. Wydawanie czasopisma wymagało dużego nakładu pracy, pieniędzy i ciągłego dopływu tekstów, a do tego zadania ogranizacja nie była gotowa. W związku z tym towarzystwo opublikowało trzy roczniki „Galicyjskiego Zbioru Historycznego" $(1853,1856,1860)$, które wypełnił swoimi badaniami naukowymi jeden autor - A. Petruszewycz.

12 Iz" L'vova v" Listopadě, „Věstnik" dlâ Rusinov" Avstrìjskoi deržavy” 28.11.1855, s. 358359; Otčety obŝestva literaturnogo Galicko-russkoj Maticy, [w:] Naukovyj sbornik", izdavaemyj literaturnym" obŝestvom" Galicko-russkoj Maticy. 1865, vo L'vově 1865, vyp. I-IV, s. XIII-XVI.

13 I., Iz" Žolkovskogo, „Zorâ Galickaâ” 4.01.1854, s. 10-12; 18.01.1854, s. 33-35; 22.02.1854, s. 94-96; Iz" Žolkovskogo, „Věstnik" dlâ Rusinov" Avstrìjskoi deržavy” 4.04.1855, s. 94-95.

14 Centralne państwowe archiwum historyczne Ukrainy we Lwowie, zesp. 148, op. 1, sygn. 38. 
Na początku 1861 r., po zmianach w austriackiej polityce wewnętrznej, Rusini galicyjscy otrzymali szansę na ożywienie działalności społecznej i kulturalnej. W nowych warunkach szybko udało się zatwierdzić nowy statut Matycy Hałycko-Ruskiej (18 VIII 1861 r.) ${ }^{15}$; towarzystwo rozpoczęło przygotowania do walnego zgromadzenia. Tak zaczął się trzeci okres historii towarzystwa, który trwał do połowy lat 60 .

Nowe możliwości rozwoju życia publicznego, wybory do sejmu galicyjskiego w 1861 r. wzbudziły duże zainteresowanie Rusinów galicyjskich do pracy oświatowej i wydawniczej. Ruska inteligencja ponownie, podobnie jak w latach 1848-1850, zwróciła uwagę na chłopów i mieszczan, ich problemy i potrzeby. W latach 1861-1862 pojawili się pierwsi ukrainofile, młodzi ludzie, którzy identyfikowali się z Ukrainą Naddnieprzańską, wspierali rozwój jednego ruskiego (ukraińskiego) języka literackiego i pozostawali w opozycji do rusofilów ${ }^{16}$. Ruska prasa regularnie komentowała bieżące wydarzenia polityczne, możliwość polsko-ruskiego porozumienia w Galicji, kwestię obrzędową, a także fakty z zagranicy. Nowe wyzwania życia społecznego wymagały zwiększenia aktywności Matycy, a także korekty jej programu oświatowego.

Jednak, jak się okazało, przywódcy organizacji nie spieszyli się. Walne zgromadzenie było nieustannie odkładane, akcja wydawnicza slabła i tematycznie była bezbarwna - wszystkie podejmowane starania miały na celu publikację podręczników gimnazjalnych do religii. Priorytetowym zadaniem dla Rusinów lwowskich było wówczas ukończenie budowy Narodnego Domu we Lwowie. W pierwszej połowie lat 60. XIX w. Matyca pozostawała jeszcze dosyć autorytatywną organizacją publiczną, jej rangę i potencjalne możliwości uznawali wszyscy Rusini galicyjscy, ale stało się jasne, że stowarzyszenie nie nadąża za tempem życia społecznego i nie może wyjść ze stagnacji po roku 1850.

W celu zmiany tak niekorzystnego stanu rzeczy zostało zwołane walne zgromadzenie, które odbyło się w dniach 19-21 VII 1864 r. ${ }^{17}$ Jego uczestnicy planowali rozpatrzeć szereg ważnych kwestii, przy czym niektóre z nich (jak np. ustalenie wspólnych zasad rozwoju języka literackiego i reguł pisowni) wykraczały poza ramy statutowych zadań Matycy. Walne zgromadzenie nie spełniło jednak oczekiwań. Nie udało się rozstrzygnąć strategicznych problemów rozwoju ruskiej literatury; stało się jasne, że Matyca nie będzie neutralnym $i$ autorytatywnym uczestnikiem dyskusji z głosem decydującym na temat rozwoju języka literackiego, publikacji książek, oświaty ludu itd. Ostatnie nadzieje na taką jej rolę zniknęły po walnym zgromadzeniu 1865 r., gdy zarząd towarzystwa zrobił wszystko, aby zapobiec przyjmowaniu ukrainofilów do jego

15 O. Suhij, Vid rusofil'stva do moskvofil'stva..., s. 211.

16 O. Sereda, Nacional 'na svidomist 'ì politična programa rannì narodovcìv u Shìdnìj Galičinì (1861-1867), „Vìsnik L'vìvs'kogo Unìversitetu. Serî̀ ìstorična” 1999, Vip. 34, s. 199-214.

17 Otčety obŝestva literaturnogo Galicko-russkoj Maticy..., s. I-LXXXVIII. 
składu ${ }^{18}$. Od tego czasu Rusini zaczęli postrzegać Matycę jako nieefektywną rusofilską organizacją społeczną, która straciła moralne prawo do monopolistycznego statusu jedynego ruskiego stowarzyszenia oświatowego w Galicji.

W latach 60. XIX w. wśród Rusinów galicyjskich nadal trwały dyskusje na temat treści i priorytetów pracy oświatowej. Zainteresowanie szkołą, literaturą edukacyjną i kształceniem młodzieży było nadal aktualne, chociaż problematyka szkoły elementarnej przestała już być główną siłą napędową oświaty ludu. Pojawiały się i znikały prywatne projekty wydawnicze mające na celu publikację lektury dla chłopów i mieszczan. Więcej uwagi niż książki przyciągały czasopisma „Dom i Szkoła” Iwana Huszałewycza (Guszalewicza), „Pyśmo do hromady” i „Hospodar” Seweryna Szechowycza (Szechowicza), „Nedila” Markyła Popela. W okresie tym nie było jeszcze godnego do naśladowania wzoru ruskiego czasopisma lub wydawnictwa seryjnego dla chłopów. Ze względu na małą liczbę czytelników (chociaż wspomniane wyżej czasopisma były adresowane nie tylko do chłopów, ale także do inteligencji wiejskiej) oraz brak funduszy, prywatne projekty oświatowe nie utrzymywały się zbyt długo.

W takich warunkach Matyca szukała niszy dla wydawanych przez siebie książek w języku ruskim. Biorąc pod uwagę doświadczenia z poprzednich lat, kiedy uwagę poświęcano głównie literaturze edukacyjnej, publikacjom naukowym i modlitewnikom, przywódcy Matycy w połowie lat 60. XIX stulecia zdecydowali się nie zmieniać priorytetów. Walne zgromadzenie w 1864 r. podjęło decyzję o wydawaniu periodyku towarzystwa. Otrzymał on tytuł „Naukowyj Sbornik"; do redakcji weszli J. Hołowacki, A. Petruszewycz i Bohdan Didycki (Dziedzicki) $^{19}$. Periodyk (od 1869 r. zmienił tytuł na „Literaturnyj Sbornik”) stał się głównym projektem wydawniczym Matycy Hałycko-Ruskiej w drugiej połowie lat 60. i na początku lat 70. XIX w. Co istotne, towarzystwo wydawało go kosztem innych publikacji. W ten sposób Matyca uprościła swój program wydawniczy i wywołała kolejną falę niezadowolenia i krytyki wśród Rusinów galicyjskich.

Czwarty okres historii Matycy rozpoczął się w drugiej połowie lat 60. XIX stulecia i trwał do końca dekady. W tym czasie nastąpiły znaczące zmiany w polityce wewnętrznej Austrii, która stała się dualistyczną monarchią austro-węgierską w 1867 r. Kraje koronne Przedlitawii, w tym Królestwo Galicji i Lodomerii, otrzymały autonomię. Oczywiście, że w warunkach autonomii

18 Otčety zasědanì literaturnogo obŝestva Galicko-russkoj maticy na dnâh" 6, 7 i 8 (18, 19 i 20) Ûl'â 1865 goda, [w:] Naukovyj sbornik", izdavaemyj literaturnym" obŝestvom" Galicko-russkoj Maticy. 1865, vo L'vově 1865, vyp. I-IV, s. 303-304.

19 Otčety obsestva literaturnogo Galicko-russkoj Maticy..., s. LXVIII-LXIX; Centralne państwowe archiwum historyczne Ukrainy we Lwowie, zesp. 148, op. 2, sygn. 7, k. 1. 
regionalnej Rusini mieli gorsze możliwości rozwoju narodowo-kulturowego w porównaniu z Polakami, chociażby ze względu na to, że byli oni stale w mniejszości w Sejmie Krajowym, nie kontrolowali administracyjnego zasobu regionu, mieli mniejsze zasoby finansowe oraz słabszy potencjał edukacyjny $\mathrm{i}$ intelektualny.

W 1868 r. w ruskiej prasie galicyjskiej pojawiło się kilka artykułów analizujących aktualny stan rzeczy. Inicjatorem dyskusji był greckokatolicki ksiądz Stepan Kaczała. Jego wnioski, które nie wzbudzały zastrzeżeń, były następujące: Rusini galicyjscy w okresie od 1848 r. niewiele zrobili dla oświaty ludu, Matyca Hałycko-Ruska nie była w stanie właściwie zorganizować pracy oświatowej, dlatego istniała potrzeba powołania innego stowarzyszenia, wspólnego dla wszystkich Rusinów (bez podziału na ruso- i ukrainofilów), wzorowanego na czeskim towarzystwie oświatowym Matice lidu ${ }^{20}$. Narodowcy (ukrainofile), którzy po 1865 r. dyskutowali o stworzeniu własnego stowarzyszenia oświatowego, zareagowali na to wezwanie i założyli w grudniu $1868 \mathrm{r}$. alternatywę dla Matycy - towarzystwo Proswita. Nie stało się ono, jak chciał S. Kaczała, wspólne dla wszystkich Rusinów galicyjskich, ale zaproponowało nieco inne niż w Matycy metody pracy i przyczyniło się do ożywienia działalności oświatowej wśród ruskiego chłopstwa i drobnomieszczństwa.

Ukrainofile, założyciele Proswity, mieli nieco inne poglądy na oświatę ludu w porównaniu z rusofilami, którzy gromadzili się wokół Matycy. Po pierwsze, deklarowali odmienne podejście do słabo wykształconych ludzi. Rusofile, wśród których było wielu wiejskich księży, patrzyli na chłopów tradycyjnie z góry, dobrze znali wady plebsu i nie oczekiwali ich szybkiego naprawienia. Starali się oni uczyć chłopów (faktycznie - pouczać) i narzucać im pewne poglądy i postawy wykorzystując swój autorytet. Taka metoda pracy, kojarzona przez chłopów z działaniami moralizatorskimi i kaznodziejskimi kapłana, nie była zbyt skuteczna, nie przebiła się przez obojętność i bierność chłopów. Ukrainofile, ludzie głównie młodzi i świeccy, nie mieli nawyków księży rusofilów. Przykładali większą wagę do odnalezienia własciwych środków przekazu, by dotrzeć do ludu, zwalczając analfabetyzm i podnosząc świadomość narodową. Wzbudzało to większe zaufanie do ich inicjatyw, choć należy przyznać, że w praktyce dystans między inteligencją a chłopstwem był znaczny. Po drugie, ukrainofile konsekwentnie i niezłomnie podkreślali, że pisać należy językiem ludowym. Kiedy rusofile (i to była ich słabość) przez cały czas wahali się między językiem ludowym i starym literackim, pisali językiem zbliżonym czy do ludowego, czy do rosyjskiego, wówczas ukrainofile tworzyli swoje teksty w galicyjskim wariancie języka ukraińskiego. To zapewniło im wielką

20 Kačala, Iz" Šel'pak”, „Slovo” 18.01.1868, s. 2; tenże, Iz" Šel'pak”, „Slovo” 18.04.1868, s. $1-2$. 
strategiczną przewagę przy realizacji programu oświatowego. Po trzecie, ukrainofile, zważywszy że ich przeciwnicy rusofile poprzez swoje prorosyjskie sympatie mieli bardzo chłodne stosunki z galicyjską władzą krajową, mogli mieć nadzieję na przynajmniej częściowe poparcie ich wysiłków ze strony rządu. Tak się też stało, Sejm Galicyjski, aby zmniejszyć wpływ rusofilów wsparł ukrainofilów subwencjami pieniężnymi dla Proswity (pierwsza transza została przydzielona w 1870 r. - 1000 złr) ${ }^{21}$, a Rada Szkolna Krajowa zatwierdziła podręczniki ich autorstwa. Dzięki tym subwencjom Proswita była w stanie ustabilizować swoją działalność i z powodzeniem przetrwała pierwsze lata.

8 IX 1870 r. odbyło się kolejne walne zgromadzenie Matycy Hałycko-Ruskiej22. Potwierdziło ono duże problemy towarzystwa. Chociaż kondycja finansowa organizacji była zadowalająca, dyskusje prowadzone podczas walnego zgromadzenia pokazały, że kierownictwo nie widzi sposobów na poprawę jakości pracy oświatowej, nie ma nowych idei. „Naukowyj Sbornik” okazał się niepopularną i nieopłacalną inicjatywą. W rzeczywistości został on zaprojektowany nie dla chłopów, ale dla ruskiej inteligencji i dla reprezentowania Rusi galicyjskiej poza granicami kraju. Dla szerszych rzeszy periodyk nie był interesujący tak ze względu na treść, jak i język (często bardzo zbliżony do rosyjskiego). Z kolei Proswita zaczęła wydawać od 1869 r. książeczki dla chłopów zwane „Zoria”, gdzie drukowano opowiadania, teksty o przyrodzie i gospodarce. Było na nie duże zapotrzebowanie. Przysporzyły one popularności i rozreklamowały ukrainofilskie towarzystwo, podczas gdy Matyca Hałycko-Ruska powoli zmniejszała swoją aktywność w pierwszej połowie lat 70. XIX w., aż do całkowitej stagnacji pod koniec tego dziesięciolecia.

W celu realizacji swoich zadań ruskie towarzystwa oświatowe w Galicji prowadziły działalność wydawniczą. Według danych statystycznych (tab. 1), w przypadku Matycy nie była ona zbyt wysoka - 46 książek w ciągu 22 lat, czyli mniej więcej dwa tytuły rocznie ${ }^{23}$.

${ }^{21}$ Instytut literatuty im. T. H. Szewczenki NAN Ukrainy (Kijów), oddział zbiorów rękopiśmiennych i tekstologii, zesp. 100, sygn. 627, 632, 642.

22 Otčet" zasédaniâ obŝogo sobraniâ členov" Galicko-russkoj Maticy otbyvšogosâ na d. 27. Avgusta (8. Sent.) 1870, [w:] Literaturnyj sbornik", izdavaemyj Galicko-russkoû Maticêิ. 1870, vo L'vově [1871], s. 117-133.

${ }^{23}$ Listę wszystkich wydań towarzystwa Matyca Hałycko-Ruska i ich nakłady patrz: O. Sedlâr, Vidavniča diâl'nist' tovaristva ,, Galic 'ko-rus 'ka maticâ” (1848-1870), „Vìsnik L'vìvs'kogo Unìversitetu. Seriâ knigoznavstvo, bìblìotekoznavstvo ta informacìjnì tehnologiï’ 2008, vip. 3, s. 98-103. 
Tab. 1. Liczba publikacji stowarzyszenia Matyca Hałycko-Ruska w latach $1849-1870^{24 *}$

\begin{tabular}{|c|c|c|c|c|c|c|c|c|c|c|}
\hline 莺 & 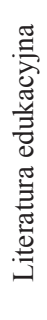 & 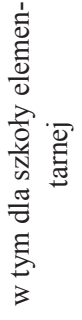 & 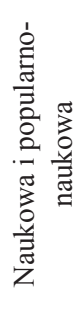 & 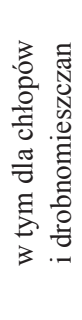 & 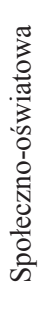 & 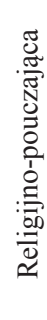 & 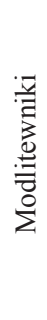 & 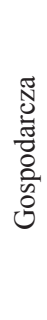 & 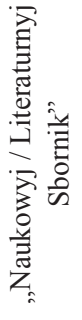 & $\begin{array}{l}\text { E్ } \\
\mathbb{N} \\
\widetilde{2}\end{array}$ \\
\hline $\begin{array}{l}\bar{\sigma} \\
\frac{\infty}{1} \\
\text { aे } \\
\infty\end{array}$ & 5 & 5 & 4 & - & 1 & 2 & 2 & - & - & 14 \\
\hline $\begin{array}{l}\stackrel{0}{0} \\
\infty \\
\stackrel{1}{1} \\
\stackrel{\infty}{\infty}\end{array}$ & 1 & 1 & 4 & 1 & - & 2 & 2 & 1 & - & 10 \\
\hline $\begin{array}{l}\tilde{b} \\
\infty \\
\frac{1}{6} \\
\infty \\
-1\end{array}$ & 8 & - & - & - & 1 & - & 1 & - & 1 & 11 \\
\hline $\begin{array}{l}\stackrel{P}{\infty} \\
\infty \\
b \\
0 \\
\infty \\
0\end{array}$ & 1 & - & 3 & 3 & - & 2 & 1 & - & 4 & 11 \\
\hline 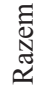 & 15 & 6 & 11 & 4 & 2 & 6 & 6 & 1 & 5 & 46 \\
\hline
\end{tabular}

Jak widać, do priorytetów tematycznych należały literatura edukacyjna (do połowy lat 50. XIX w. dla szkoły ludowej, w latach 60. - dla gimnazjum), literatura naukowa i popularnonaukowa, od $1865 \mathrm{r}$. - periodyk towarzystwa. Matyca Hałycko-Ruska regularnie wydawała również literaturę religijną i moralizatorską (w tym trzy żywoty świętych) i modlitewniki. Natomiast prawie nie było książek o tematyce ekonomicznej (z wyjątkiem opublikowanej w 1856 r. pozycji o pszczelarstwie Lewa Treszczakowskiego) i nie było w ogóle odrębnych osobnych wydań literatury pięknej.

${ }^{24}$ W tabeli nie uwzględniono publikacji statutów i rocznych sprawozdań „Hałycko-Ruskiej Matyci”. Gramatyka języka ruskiego J. Hołowackiego (1849) została wzięta pod uwagę jako jedna edycja, choć pierwotnie była drukowana w dwóch częściach. 
Tab. 2. Sumaryczny nakład (w egzemplarzach) publikacji stowarzyszenia Matyca Hałycko-Ruska w latach 1849-1870

\begin{tabular}{|c|c|c|c|c|c|c|c|c|c|c|}
\hline 莺 & 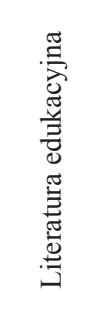 & 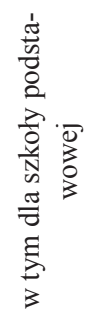 & 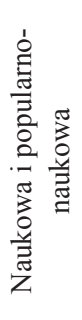 & 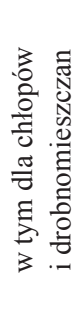 & 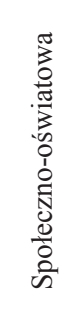 & 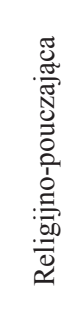 & 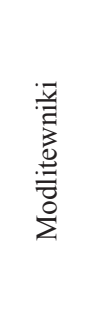 & 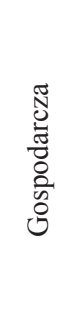 & 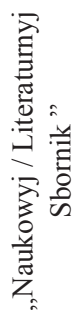 & 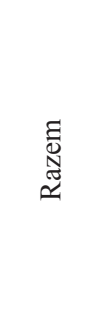 \\
\hline $\begin{array}{l}\bar{n} \\
\frac{\infty}{1} \\
\stackrel{\alpha}{\infty}\end{array}$ & 46000 & 46000 & 3000 & - & 1000 & 1000 & 12000 & - & - & 63000 \\
\hline 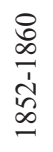 & 1000 & 1000 & 2000 & 500 & - & 1500 & 8500 & 2500 & - & 15500 \\
\hline $\begin{array}{l}\tilde{b} \\
\infty \\
\frac{1}{6} \\
\infty \\
\infty\end{array}$ & 8000 & - & - & - & 1000 & - & 3000 & - & $500^{25}$ & 12500 \\
\hline $\begin{array}{l}\stackrel{R}{\infty} \\
\frac{1}{1} \\
\dot{0} \\
\infty \\
0\end{array}$ & 1000 & - & 2000 & 2000 & - & 4000 & 5000 & - & 1200 & 13200 \\
\hline $\begin{array}{l}\text { ฮ్ల } \\
\text { त్ } \\
\approx\end{array}$ & 56000 & 47000 & 7000 & 2500 & 2000 & 6500 & 28500 & 2500 & 1700 & 104200 \\
\hline
\end{tabular}

Tabela druga zawiera nakłady wydań Matycy. W największych nakładach towarzystwo publikowało podręczniki dla szkoły elementarnej (maksymalna liczba to 20000 egzemplarzy elementarza I. Hurkewycza (1851)) i modlitewniki (od 3000 do 10000 egzemplarzy). Podręczniki do gimnazjum drukowano w nakładzie 1000 egzemplarzy, książki naukowe i popularnonaukowe - z reguły 500 egzemplarzy, „Naukowyj/Literaturnyj Sbornik” - 500 egzemplarzy w 1865 r. i w 300 egzemplarzach w kolejnych latach. Członkowie stowarzyszenia otrzymywali wydawnictwa bezpłatnie. Biorąc pod uwagę niewielką liczbę członków (1850 r. - 193, 1858 r. - 209, 1864 r. - 240, 1870 r. - 264, ale nie

25 Publikacja „Naukowego Sbornika” za pierwszy kwartał 1865 r. została wydrukowana w nakładzie 1000 egz., kolejne trzy wydania kwartalne - 500 egz. 
wszyscy opłacali składki i byli zainteresowani bieżącą działalnością towarzystwa) ${ }^{26}$, większą część nakładów Matyca sprzedawała. Proces ten był powolny, niektóre wydania zbywała przez dziesięciolecia, stopniowo obniżając ich cenę.

Tab. 3. Sumaryczna objętość (w arkuszach drukarskich) publikacji towarzystwa Matyca Hałycko-Ruska w latach 1849-1870

\begin{tabular}{|c|c|c|c|c|c|c|c|c|c|c|}
\hline 䔍 & 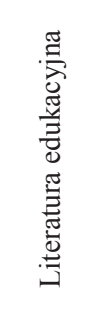 & 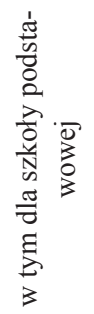 & 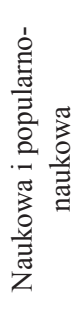 & 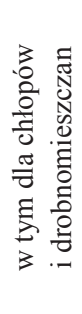 & 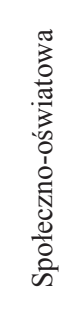 & 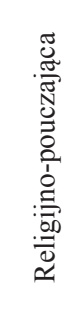 & 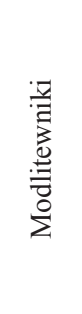 & 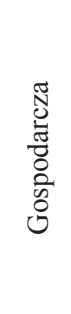 & 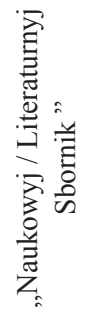 & 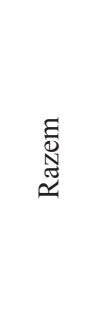 \\
\hline $\begin{array}{l}\vec{n} \\
\infty \\
\overline{1} \\
\text { वे } \\
0\end{array}$ & 39,26 & 39,26 & 8,94 & - & 15,88 & 3,25 & 1,42 & - & - & 68,75 \\
\hline $\begin{array}{l}8 \\
\infty \\
\frac{1}{1} \\
\tilde{N} \\
\infty\end{array}$ & 6,00 & 6,00 & 59,82 & 22,88 & - & 6,62 & 17,33 & 5,12 & - & 94,89 \\
\hline $\begin{array}{l}\tilde{b} \\
\infty \\
\frac{1}{b} \\
\infty\end{array}$ & 162,94 & - & - & - & 26,81 & - & 5,98 & - & 27,38 & 223,11 \\
\hline $\begin{array}{l}\stackrel{0}{\infty} \\
\infty \\
1 \\
b \\
\infty \\
\infty\end{array}$ & 30,69 & - & 7,00 & 7,00 & - & 2,56 & 5,00 & - & 92,48 & 137,73 \\
\hline $\begin{array}{l}\text { Eี } \\
\text { त्र } \\
\text {. }\end{array}$ & 238,89 & 45,26 & 75,76 & 29,88 & 42,69 & 12,43 & 29,73 & 5,12 & 119,86 & 524,48 \\
\hline$a^{\circ}$ & 45,55 & 8,63 & 14,45 & 5,70 & 8,14 & 2,37 & 5,67 & 0,98 & 22,85 & 100 \\
\hline
\end{tabular}

Tabela trzecia zawiera wskaźniki objętości (w arkuszach drukarskich) wydań Matycy. Pokazują one także, że najważniejszą rolę w programie wydawniczym towarzystwa zajmowała literatura edukacyjna ( $\mathrm{z}$ wyraźną przewagą

26 O Sedlâr, „Galic'ko-rus'ka maticâ”: zavdannâ, organizaciâ, členi tovaristva (1848-1870), „Ukraïna: kul'turna spadŝina, nacional'na svìdomìst', deržavnìst”” 2012, vip. 21, s 680-681. 
podręczników do gimnazjum), periodyk organizacji (pod koniec lat 60. XIX w. ukrainofile uważali, że poza nim stowarzyszenie rusofilskie nie wydaje nic więcej) $)^{27}$ i publikacje naukowe.

Należy również zauważyć, ile publikacji Matycy Hałycko-Ruskiej mogło być przeznaczonych dla mało wykształconych chłopów i mieszczan, dla rozwoju których, samo stowarzyszenie zostało założone. Wskaźniki, podane w tabeli czwartej, pokazują, że było 23 takich tytułów, to jest dokładnie połowa publikacji.

Tab. 4. Wskaźniki publikacji towarzystwa Matyca Hałycko-Ruska dla oświaty ludu ${ }^{28}$ w latach $1849-1870$

\begin{tabular}{|c|c|c|c|c|c|c|}
\hline 䔍 & 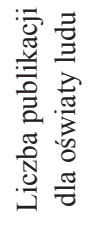 & 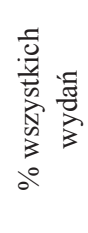 & 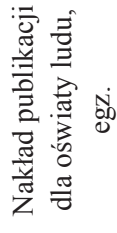 & 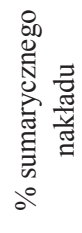 & 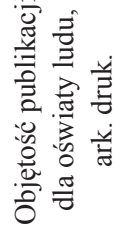 & 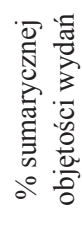 \\
\hline 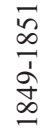 & 9 & 64,28 & 59000 & 93,65 & 43,93 & 63,90 \\
\hline 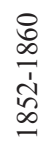 & 7 & 70,00 & 14000 & 90,32 & 57,95 & 61,07 \\
\hline $\begin{array}{l}8 \\
\infty \\
\infty \\
\text { à } \\
\infty\end{array}$ & 16 & 66,67 & 73000 & 92,99 & 101,88 & 62,26 \\
\hline $\begin{array}{l}\sqrt{0} \\
\infty \\
\frac{1}{0} \\
\infty\end{array}$ & 1 & 9,09 & 3000 & 24,00 & 5,98 & 2,68 \\
\hline
\end{tabular}

\footnotetext{
27 Visti, ,Pravda” 15.10.1868, s. 455-456.

28 Publikacje obejmują: literaturę edukacyjną dla szkół elementarnych, literaturę popularnonaukową dla zwykłych ludzi, wydania o tematyce religijno-pouczającej i gospodarczej oraz modlitewniki. Większość z nich (oczywiście oprócz literatury edukacyjnej) była również przeznaczona dla przedstawicieli inteligencji. Pozostałe wydania „Matycy” były całkowicie lub prawie całkowicie dla inteligencji.
} 


\begin{tabular}{|c|c|c|c|c|c|c|}
\hline $\begin{array}{l}\stackrel{0}{\infty} \\
\frac{1}{1} \\
\dot{0} \\
\infty\end{array}$ & 6 & 54,54 & 11000 & 83,33 & 14,56 & 10,57 \\
\hline$\frac{\stackrel{2}{\infty}}{\frac{1}{0}}$ & 7 & 31,81 & 14000 & 54,26 & 20,54 & 5,69 \\
\hline $\begin{array}{l}\stackrel{0}{\infty} \\
\frac{1}{\dot{1}} \\
\frac{\infty}{\infty}\end{array}$ & 23 & 50,00 & 87000 & 83,49 & 122,42 & 23,34 \\
\hline
\end{tabular}

Dobrze widać, że jeśli w latach 1849-1860 przeważały publikacje dla ludu, to w latach 60. XIX w. znajdowały się na marginesie programu wydawniczego Matycy. Towarzystwo, powołane, by zajmować się oświatą ludu, faktycznie drukowało lekturę dla inteligencji, w dodatku bardzo wyspecjalizowaną, która nie mogła liczyć na zainteresowanie i szeroki popyt. Nawet „Naukowyj/Literaturnyj Sbornik", który powinien mieć uniwersalny charakter, okazał się miejscem do publikacji źródeł historycznych, badań naukowych z różnych dziedzin humanistyki, sprawozdawczej dokumentacji Matycy i Komisji Narodnego Domu; literatura piękna zajmowała w nim zaledwie około $10 \%$ treści ${ }^{29}$. Fatalna dla organizacji okazała się pierwsza połowa lat 60. XIX w., kiedy towarzystwo praktycznie przestało wydawać książki oświatowe dla ludu i zdecydowało się skoncentrować na publikacji czasopisma nie oświatowego, a naukowego w związku z tym interesującego dla bardzo wąskiego grona czytelników.

Towarzystwo ukrainofilskie Proswita rozpoczęło regularną działalność wydawniczą w 1869 r. Nie uwzględniając statutów, odezw i innych drobnych druków, których edycja rozpoczęła się pod koniec 1868 r., w latach 1869-1870 Proswita opublikowała osiem tytułów ${ }^{30}$. Ich sumaryczna objętość wynosiła około 21 arkuszy drukarskich, a tematyka różniła się zasadniczo od wydań konkurentów rusofilskich. Proswita skupiała się przede wszystkim, na literaturze do czytania. Towarzystwo opublikowało cztery wydania czytanki dla ludu „Zoria”, „Narodnyj Kalendar” na 1870 r. (Matyca nie wydała żadnego kalendarza w całym badanym okresie). Łącznie ponad $80 \%$ objętości produkcji wydawniczej Proswity w latach 1869-1870 stanowiły małe, dobrze dostosowane do potrzeb pospolitych ludzi, teksty artystyczne i popularnonaukowe w czytankach. To był inny, bardziej perspektywiczny, aniżeli w Matycy Hałycko-Ruskiej,

${ }^{29}$ O. Sedlâr, Serìal'nì vidannâ ,,Galic'ko-rus'koï maticì”. Proekti ta ïh realizaciâ (18481847 rr.), „Vìsnik L'vìvs'kogo Unìversitetu. Serìa knigoznavstvo, bỉblìotekoznavstvo ta informacìjnì tehnologiï” 2011, vip. 6, s. 74.

30 Tovaristvo "Prosvita” u L'vovi. Pokažčik vidan'. 1868-1939, układ. O.G. Berbeka, L.V. Golovata, L'vìv 1996, s. 23-28. 
format działalności oświatowej, który szybko pomógł Proswicie stać się rozpoznawalną marką.

Podsumowując powyższe rozważania, można wyciągnąć kilka ważnych wniosków. Po pierwsze, kwestia oświaty ludu z 1848 r. była stale obecna w publicznym dyskursie Rusinów galicyjskich. Dyskusje na ten temat trwały nieustannie, oświatowe organizacje społeczne działały, ukazywały się książki. Na przełomie lat 60. i 70. XIX w. zaczęto postrzegać oświatę ludu jako kompleksowy program działań organizacyjnych i promocyjnych oraz publikacji i rozpowszechniania literatury popularnej wśród chłopów i mieszczan. Wcześniej, i to dobrze pokazuje przykład Matycy Hałycko-Ruskiej, praca oświatowa została skierowana do różnych grup społecznych, publikacje popularne były nieliczne, ukazywały się nieregularnie - to wszystko istotnie obniżało skuteczność wysiłków liderów społecznych, którzy chcieli angażować się w edukację ludu.

Głównym ośrodkiem pracy oświatowej wśród Rusinów galicyjskich w latach 50. i 60. XIX w. było towarzystwo Matyca Hałycko-Ruska. W jej skład wchodziło stosunkowo niewielu członków, ale organizacja otrzymywała wsparcie Kościoła greckokatolickiego i przez długi czas była uważana za zbiorowego przedstawiciela Rusinów galicyjskich w kulturowej i intelektualnej przestrzeni Austrii i ogólnie Europy Środkowo-Wschodniej. Z jednej strony to ułatwiało działalność towarzystwa, które przez długi czas nie odczuwało konkurencji, a z drugiej nakładało na nie zbyt wiele zobowiązań, przeszkadzało skupić się na publikacji literatury popularnej i oświatowej dla chłopów i drobnomieszczan. Przynależność większości kierowników stowarzyszenia do lwowskiego greckokatolickiego kleru i zarazem do rusofilów galicyjskich spowodowała specyficzny charakter programu wydawniczego Matycy z naciskiem na literaturę religijno-pouczającą, badania i promocję starożytnej historii Rusi, rozwoj języka ruskiego i literatury w duchu wspólnej tradycji dla wszystkich Słowian wschodnich.

Z różnych powodów (niegotowość liderów ówczesnych Rusinów galicyjskich do aktywnej pracy społecznej, ich niedostateczne zrozumienie strategii i taktyki pracy oświatowej, brak autorów, którzy mogliby pisać ciekawe teksty popularne, brak funduszy na publikację, małoefektywne rozpowszechnianie wydań) Matyca nie była w stanie we właściwy sposób realizować statutowych zadań. Jej oddziaływanie na ruski lud było minimalne.

Towarzystwo Proswita stało się alternatywą dla Matycy pod koniec lat 60 . XIX w. z uwagi na narodowo-kulturowe przeświadczenia (ukrainofilstwo) oraz ze względu na tematyczne priorytety publikacji (nacisk na teksty artystyczne i popularnonaukowe w czytankach dla włościan). Początkowo było to również stowarzyszenie inteligencji bez wyraźnego współudziału chłopów i mieszczan. Jednak w latach 70. XIX w. taktyka Proswity okazała się bardziej perspektywiczna i skuteczniejsza, aniżeli Matycy, dlatego galicyjscy rusofile założyli 
nowe towarzystwo oświatowe (Towarzystwo im. Mychajła Kaczkowskiego) z podobną strategią działania, a ruscy chłopi, tworząc pierwsze czytelnie, starali bardziej aktywnie angażować się w ruch oświatowy.

\section{Bibliografia}

Źródła archiwalne

Centralne państwowe archiwum historyczne Ukrainy we Lwowie: Zespół 148, Towarzystwo „Hałycko-Ruska Matyca”,

op. 1 , sygn. 38 ,

op. 2, sygn. 7.

Instytut literatuty im. T. H. Szewczenki NAN Ukrainy (Kijów), oddział zbiorów rękopiśmiennych i tekstologii: Zespół 100, Iwan Bełej,

sygn. 627 ,

sygn. 632,

sygn. 642 .

Źródła drukowane

Golovna Rus'ka Rada (1848-1851). Protokoli zasidan'i kniga korespondencï, za red. O. Turîâ, uporâdn. U. Krištalovič ta İ. Svarnik, L'vìv 2002.

Grabovič’ paroch" Kovalěvki, Z" Stanislavovskogo, „Zorâ Galicka” 29.01.1851, s. 70-71. I., Iz" Žolkovskogo, ,Zorâ Galickaâ” 4.01.1854, s. 10-12; 18.01.1854, s. 33-35; 22.02.1854, s. 94-96.

Istoričeskij očerk" osnovaniâ Galicko-ruskoi Maticě i spravozdan'e pervogo soboru učenyh" russkih" i lubitelej narodnogo prosvěŝeniâ, sostavleno Â. Golovackim", vo L'vově 1850 .

Iz" L'vova v" Listopadě, „Věstnik" dlâ Rusinov" Avstrìjskoi deržavy” 28.11.1855, s. 358359.

Iz" Žolkovskogo, „Věstnik" dlâ Rusinov" Avstrìjskoi deržavy” 4.04.1855, s. 94-95.

Kačala S., Iz" Šel'pak", ,Slovo” 18.01.1868, s. 2.

Kačala S., Iz" Šel'pak", „Slovo” 18.04.1868, s. 1-2.

Korespondenciâ Âkova Golovac'kogo v lïtah 1835-49, vidav K. Studins'kij, L'vìv 1909.

Otčet" zasědaniâ obŝogo sobraniâ členov" Galicko-russkoj Maticy otbyvšogosâ na d. 27. Avgusta (8. Sent.) 1870, [w:] Literaturnyj sbornik", izdavaemyj Galicko-russkoû Maticeû. 1870, vo L'vově [1871], s. 117-133.

Otčety obŝestva literaturnogo Galicko-russkoj Maticy, [w:] Naukovyj sbornik", izdavaemyj literaturnym" obŝestvom" Galicko-russkoj Maticy. 1865, vo L'vově 1865, vyp. I-IV, s. I-LXXXVIII.

Otčety zasědanij literaturnogo obŝestva Galicko-russkoj maticy na dnâh" 6, 7 i 8 (18, 19 i 20) Ûl'â 1865 goda, [w:] Naukovyj sbornik", izdavaemyj literaturnym" obŝestvom" Galicko-russkoj Maticy. 1865, vo L'vově 1865, vyp. I-IV, 283-310. 
Pašuk V., Religìno-cerkovna tematika u perših vidannâh Tovaristva „Prosvita” 18681871 rr., [w:] İstoriâ religiï v Ukraïnì. Kn. 1, L’vìv 2014, s. 217-235.

Pašuk V., Tovaristvo „Prosvita”. Perši vidannâ na social'no-ekonomičnu tematiku. 18691874 rr., „Narodoznavčì Zošiti” 2012, nr 6, s. 1171-1186.

Pašuk V., Tovaristvo „,Prosvita”. Započatkuvannâ vidavničoï diâl'nostì, „,Visnik L'vìvs'koï Komercìnoï Akademiï. Serîa gumanìtarnì nauki” 2011, vip. 10, s. 170-182.

Sedlâr O., „Galic'ko-rus'ka maticâ”: zavdannâ, organizaciâ, členi tovaristva (18481870), „Ukraïna: kul'turna spadŝina, nacional'na svìdomìst', deržavnìst”" 2012, vip. 21, s. 668-692.

Sedlâr O., Serial'nì vidannâ „,Galic'ko-rus 'koï maticì”. Proekti ta ïh realizaciâ (18481847 rr.), „Vìsnik L'vìvs'kogo Unìversitetu. Serìa knigoznavstvo, bìblìotekoznavstvo ta informacìnì tehnologiì” 2011, vip. 6, s. 61-77.

Sedlâr O., Vidavniča diâl'nìst' tovaristva ,, Galic'ko-rus 'ka maticâ” (1848-1870), „Vìsnik L'vìvs'kogo Unìversitetu. Serîa knigoznavstvo, bìblìotekoznavstvo ta informacìnì tehnologiï" 2008, vip. 3, s. 76-115.

Sereda O., Nacional'na svidomist' i politična programa rannih narodovcìv u Shidnij Galičinì (1861-1867), „Vìsnik L'vìvs'kogo Unìversitetu. Serìa ìstorična” 1999, vip. 34, s. 199-214.

Steblij F.I., Kril' M.M., Halickaâ matica vo L'vove [w:] Slavânskie maticy. XIX vek. Č. 1, Moskva 1996, s. 190-233.

Suhij O., Vid rusofil'stva do moskvofil'stva (rosijs'kij činnik u gromads'kij dumci ta suspil'no-političnomu žittì galic'kih ukrä̈ncìv u XIX stolitti), L'vìv 2003.

Tovaristvo „Prosvita” u L'vovì. Pokažčik vidan'. 1868-1939, uklad. O.G. Berbeka, L.V. Golovata, L'vìv 1996.

Vendland A.V., Rusofili Galičini. Ukraïns'kì konservatori mǐz Avstrîêu ta Rosiê̂u, 18481915, L'vìv 2015.

Visti, ,Pravda” 15.10.1868, s. 455-456.

Z" Bolehovskogo, o postupě škol" i izobrazovanii narodnom”, „Věstnik" dlâ Rusinov" Avstrìjskoi deržavy" 24.07.1851, s. 322-323; 26.07.1851, s. 326.

Z" Sambörskogo okruga 8/20 maă, „Věstnik" dlâ Rusinov" Avstrìjskoi deržavy” 12.06.1851, s. 251-252. 
